University of Tennessee College of Law

Legal Scholarship Repository: A Service of the Joel A. Katz Law Library

$5-26-2017$

\title{
Looking Up in the Data-Driven Economy
}

\author{
Maurice Stucke \\ University of Tennessee College of Law \\ Ariel Ezrachi \\ University of Oxford
}

Follow this and additional works at: https://ir.law.utk.edu/utklaw_facpubs

\section{Recommended Citation}

Stucke, Maurice and Ezrachi, Ariel, "Looking Up in the Data-Driven Economy" (2017). UTK Law Faculty Publications. 129.

https://ir.law.utk.edu/utklaw_facpubs/129

This Article is brought to you for free and open access by the Faculty Work at Legal Scholarship Repository: A Service of the Joel A. Katz Law Library. It has been accepted for inclusion in UTK Law Faculty Publications by an authorized administrator of Legal Scholarship Repository: A Service of the Joel A. Katz Law Library. For more information, please contact eliza.boles@utk.edu. 


\section{THE UNIVERSITY OF TENNESSEE KNOXVILLE}

COLLEGE OF LAW
Legal Studies

Research Paper Series

Research Paper \#333

September 2017

\title{
Looking Up in the Data-Driven Economy
}

\author{
Maurice E. Stucke \\ $\boldsymbol{\&}$ \\ Ariel Ezrachi
}

CPI Antitrust Chronicle (May 2017)

This paper may be downloaded without charge

from the Social Science Research Network Electronic library at: http://ssrn.com/abstract=2975510

Learn more about the University of Tennessee College of Law: law.utk.edu 


\section{LOOKING UP IN THE DATA-DRIVEN ECONOMY}

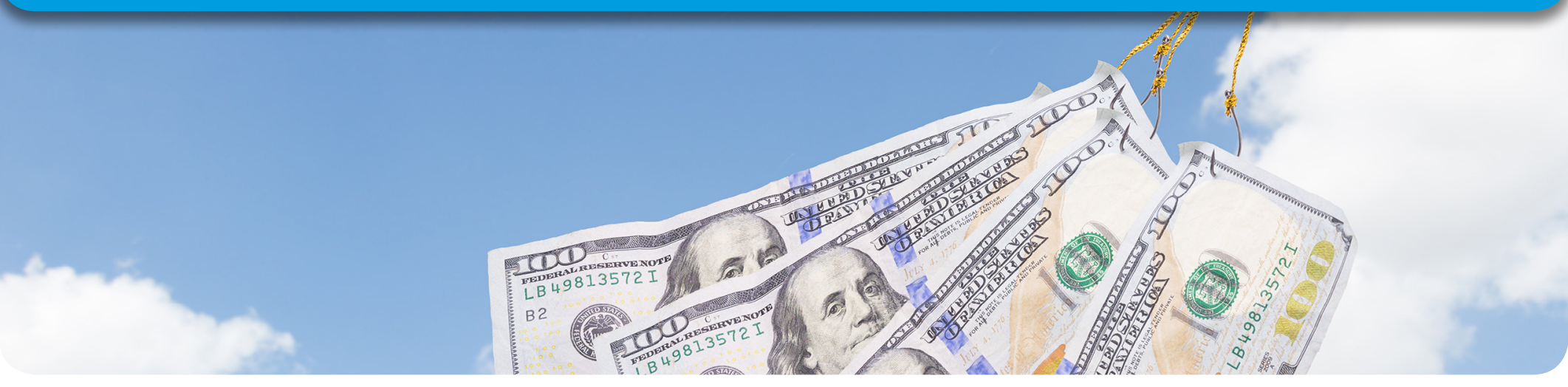

\section{BY MAURICE E. STUCKE ${ }^{1} \&$ ARIEL EZRACHI²}

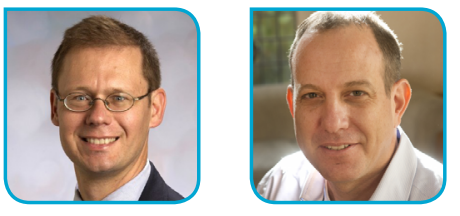

\section{INTRODUCTION}

How competitive is our market economy? Not as much as it ought to be. And the growth of big data threatens to make things even worse. Antitrust regulators already struggle to keep markets competitive. How will they fare in economies increasingly dominated by a few superplatforms?

Before we discuss the e-monopsony and e-scraper problems, it's worth reviewing the state of antitrust policy in the U.S. We are increasingly realizing the market failures and shortcomings of U.S. antitrust policy (aside from cartel enforcement) over the past 35 years. In April 2016, the Obama White House issued an executive order ${ }^{3}$ and report ${ }^{4}$ on the state of competition in the U.S. The report identified several disturbing signs of competition's decline since the 1970s. Competition appears to be decreasing in many economic sectors, including a decades-long decline in the number of new businesses being started and in the rate at which workers change jobs. At the same time, many industries appear to have become more concentrated, with profits increasingly falling into the hands of fewer firms.

\footnotetext{
1 Professor, University of Tennessee College of Law; Co-founder, The Konkurrenz Group.

2 Slaughter and May Professor of Competition Law, The University of Oxford; Director, Oxford University Centre for Competition Law and Policy.

3 The White House, Office of the Press Secretary, Executive Order - Steps to Increase Competition and Better Inform Consumers and Workers to Support Continued Growth of the American Economy (April 15, 2016), https://obamawhitehouse.archives.gov/the-press-office/2016/04/15/executiveorder-steps-increase-competition-and-better-inform-consumers.
}

4 Council of Economic Advisers, Issue Brief: Benefits of Competition and Indicators of Market Power (April 2016). 
These concerns have been noticed by scholars at a recent University of Chicago conference, ${ }^{5}$ The Economist, ${ }^{6}$ The $^{2}$ Atlantic, ${ }^{7}$ antitrust lawyers ${ }^{8}$ and the Harvard Business School. ${ }^{9}$ The solution is more competition, which traditionally has meant more robust antitrust enforcement. But ensuring competition today means looking at its next frontier: our online e-commerce environment. It means understanding the shift from competition as we know it to the era of big data and big analytics, which is radically changing our markets and competitive ecosystem.

\section{NEITHER G00D, BAD, NOR NEUTRAL}

Big data, sophisticated computer algorithms, and artificial intelligence are not inherently good or bad, but that doesn't mean their effects on society are neutral. Their nature depends on how firms employ them, how markets are structured, and whether firms' incentives are aligned with society's interests. At times, big data and big analytics can promote competition and our welfare by making information more easily available and by providing access to markets.

However, we cannot uncritically assume that we will always benefit. As we explore in our book Virtual Competition, ${ }^{10}$ big data and big analytics can enable some online sellers to tacitly collude and engage in behavioral discrimination. A third potential anticompetitive scenario involves the dominant "super-platforms."

With the rise of the super-platforms, we tend to look down (on their effect on consumers) rather than up (their effect on sellers and upstream providers). In looking down it seems like Google, Amazon and Facebook are using their power in the marketplace to deliver great value to us - wrestling lower prices from producers in the case of Amazon, bringing news onto a single platform in the case of Facebook, and organizing the world's information, in the case of Google.

While these companies appear to be furthering our interests, a closer look reveals how these super-platforms may wield their power downstream to harm us, the consumer. As Virtual Competition explores, the super-platforms can use our personal data to better price discriminate and their disincentive to protect our privacy (and promote technologies that do).

Less discussed, but of significant concern, are the upstream effects of these super-platforms. They have the power to harm many of the companies from whom they buy or acquire content — and that harm ultimately harms us. With these digital gatekeepers, the distinction between seller and consumer blurs. Many of us are not only consumers but producers. For example, you may be an author, journalist, musician, photographer or seller on Amazon. Hence the power being brought to bear on the producer — theoretically to benefit the consumer - is actually being brought to bear also on the consumer, as a producer.

In looking up rather down, we see how the super-platforms can squeeze millions of sellers, including photographers, photojournalists, writers, journalists and musicians. These super-platforms can use their significant market power to drive down earnings, while tossing a few pennies from each dollar they take from us back at us. Our competition laws deal with this kind of buyer power. These concerns, however, are often low on the enforcement agenda due to the indirect effects on "consumer welfare," which is often measured by the price you pay for the goods or service. So if we stream the YouTube video ostensibly for "free," the assumption is that our welfare is maximized. In the digital age, that urgently needs to change.

5 The University of Chicago worries about a lack of competition: Its economists used to champion big firms, but the mood has shifted, The EconomisT, April 12, 2017, http://www.economist.com/news/business/21720657-its-economists-used-champion-big-firms-mood-has-shifted-universitychicago?frsc $=\mathrm{dg} \% 7 \mathrm{Cc}$; videos of the panels are available at University of Chicago Booth School of Business, Stigler Center, Is There A Concentration Problem In America? (March 27-29, 2017), https://research.chicagobooth.edu/stigler/events/single-events/march-27-2017.

6 A Giant Problem: The Rise of the Corporate Colossus Threatens Both Competition and the Legitimacy of Business, The Economist, Sept. 17, 2016, http://www.economist.com/news/leaders/21707210-rise-corporate-colossus-threatens-both-competition-and-legitimacy-business.

7 Derek Thompson, America's Monopoly Problem: How big business jammed the wheels of innovation, The AtLANTIc, Oct. 2016, https://www.theatlantic. com/magazine/archive/2016/10/americas-monopoly-problem/497549/.

8 http://www.nysba.org/am2017Antitrust/.

9 Michael E. Porter et al., Problems Unsolved and A Nation Divided: The State of U.S. Competitiveness 2016, Harvard Business School, Sept. 2016, http://www.hbs.edu/competitiveness/Documents/problems-unsolved-and-a-nation-divided.pdf.

10 Ariel Ezrachi \& Maurice E. Stucke, Virtual Competition: The Promise and Perills of the Algorithm-Driven Economy (Harvard University Press 2016), hittp://www. hup.harvard.edu/catalog.php?isbn=9780674545472. 
Not only are the upstream sellers poorer. The super-platform's economic power can translate into political power: As sellers and consumers increasingly rely on these gatekeepers, the super-platforms can shape our political views and the public debate. As the spate of fake news attests, our social fabric and ultimately our welfare are threatened.

\section{E-MONOPSONY}

Let us begin with the e-monopsony. Our discussion differs from the textbook monopsony definition. A monopsony typically is characterized as the only or dominant buyer in town. Think of the factory in the one-factory town. As one court noted, "Because the factory is the sole employer - the sole purchaser of labor-it can dictate wages, benefits, and working conditions regardless of how large the town's population."11 Our concern involves the super-platform's anticompetitive use of power upstream.

Take, for example, publishers who confront a dominant book buyer. In a competitive market, publishers can play bookstores off each other to secure a fair price for their and their writers' work. The dominant book buyer, on the other hand, depresses the price it pays publishers for the books. It effectively transfers wealth from the publishers and authors to itself. It gets worse for authors who rely on the e-monopsony to publish and distribute their e-books. They must concede to even more onerous demands, such as the e-monopsony paying the author by the actual number of pages that you and I read of that e-book. ${ }^{12}$

Not only is this tracking creepy, it reflects the e-monopsony's power both upstream and downstream. The e-monopsony depresses the price it pays authors below competitive levels. But these price reductions do not necessarily benefit readers. We pay for the entire e-book; the authors' royalties are slashed if they can't hold our attention until the last page; and the e-monopsony pockets the extra profits. Its anticompetitive tactics, instead of promoting economic growth and welfare, can reduce employment, reduce quality and hinder innovation.

It gets worse. An e-monopsony, like a monopoly, can use its trove of personal data to price discriminate both up- and down-stream. The e-monopsony, knowing who is reading each author's work, how far the reader gets and how loyal the reader is, can charge the author's loyal fans higher prices. Moreover, the e-monopsony can collect personal data on the authors, including their finances (e.g. when college and credit card payments are due). It pays each author only the minimum amount needed for that author to produce the e-book. Authors with a slimmer financial cushion can be more easily exploited; consumers do not necessarily benefit. Indeed, writing-related income of full-time book authors, the Authors Guild found, dropped 30 percent from $\$ 25,000$ in 2009 to $\$ 17,500$ in 2015. Part-time authors saw their writing income decline 38 percent from $\$ 7,250$ to $\$ 4,500 .^{13}$

The EU and U.S. competition laws target these anticompetitive practices, but many competition agencies are not lifting their eyes.

One example is Amazon. The U.S. Department of Justice ("DoJ"), during the Obama administration, heard complaints about how the dominant online retailer was abusing its power. ${ }^{14}$ One concern was predatory pricing: Amazon was pricing e-books below cost in order to cement its power, and would eventually seek to reap the rewards by inflating prices and retarding innovation. Another concern was that Amazon retaliated against publishers that tried to take advantage of Apple's more advanced e-books platform. The Authors Guild pointed out how Amazon often removed the online "buy" buttons for titles from publishers that did not agree to Amazon's contract terms. Others complained about Amazon's exclusive distribution agreements with authors. The DoJ responded that the predatory pricing claims were "speculative."15 It hailed Barnes \& Noble's entry with its Nook e-reader as shedding any "doubt on the future of e-books agency pricing." 16 The DoJ never revisited its predictions, as Nook's sales plunged from \$933 million in 2012 to \$780 million in 2013 to \$506 million in 2014 to $\$ 264$ million in 2015 to $\$ 192$ million in $2016 .{ }^{17}$ Nor did the DoJ investigate after the Authors Guild, the American Booksellers

11 Sprint Nextel Corp. v. AT \& T Inc., 821 F. Supp. 2d 308, 324 n. 27 (D.D.C. 2011).

12 Anita Singh, Amazon to Pay Kindle Authors Only for Pages Read, The Telegraph, June 22, 2015, http://www.telegraph.co.uk/technology/ amazon/11692026/Amazons-to-pay-Kindle-authors-only-for-pages-read.html.

13 The Authors Guild, The Wages of Writing, Key Findings from The Authors Guild 2015 Member Survey, https://www.authorsguild.org/wp-content/ uploads/2015/09/WagesofWriting Final 10-22-15.pdf.

14 U.S. v. Apple, Inc., 889 F. Supp. 2 d 623 (S.D.N.Y. 2012).

15 Id. at 641.

16 ld.

17 Barnes \& Noble 2016 Annual Report, http://files.shareholder.com/downloads/BKS/3973691008x0x900955/6C96EEA0-D250-4C61-8636- 
Association, the Association of Authors' Representatives and Authors United described Amazon's anticompetitive practices. ${ }^{18}$ Nor did the recent report by the Institute for Local Self-Reliance of Amazon's anticompetitive tactics awake the DoJ from its slumber. ${ }^{19}$ Nor did the European Commission's recent and successful challenge of Amazon's anticompetitive conditions on publishers. ${ }^{20}$

\section{E-SCRAPER}

Let us now explore the e-scraper. Even if the super-platform is not a buyer, it can distort competition upstream by scraping the viability of upstream providers. Let us illustrate. With its dominant search engine and control of the Android mobile operating system, Google has tremendous power. The U.S. Federal Trade Commission ("FTC”) investigated allegations that Google "unfairly ‘scraped,' or misappropriated, the content of certain competing websites, passed this content off as its own, and then threatened to delist these rivals entirely from Google's search results when they protested the misappropriation of their content." ${ }^{21}$ Basically Google was stealing content from other providers operating on its super-platform. Google's scraping, the FTC Bureau of Competition found, was anticompetitive: "the natural and probable effect of Google's conduct is to diminish the incentives of [rivals] to invest in, and to develop, new and innovative content, as the companies cannot fully capture the benefits of their innovations."22 This theft, the FTC legal staff found after its lengthy investigation, violated the antitrust laws, and should be stopped. Google's threat "also sent a message to the broader marketplace that Google could, and would, use its monopoly power over search to extract the fruits of its rivals' innovations." ${ }^{23}$ The FTC Commissioners, however, never sued. Instead, the FTC, in a highly unorthodox move, closed its investigation in early 2013 after Google promised to stop stealing. ThenFTC Chairman Jon Leibowitz and Commissioner Julie Brill, in a press release, expected the FTC "to enforce vigorously" Google's voluntary commitment not to scrape. ${ }^{24}$ Both have left the FTC. Google reportedly continues to scrape. As one complainant, Getty Images, notes, "Artists need to earn a living in order to sustain creativity and licensing is paramount to this; however, this cannot happen if Google is siphoning traffic and creating an environment where it can claim the profits from individuals' creations as its own." ${ }^{25}$ Neither the FTC nor DoJ, during the Obama administration, stopped Google. So American firms have turned to the European Commission, which is currently investigating Google for scraping. ${ }^{26}$

\section{BA7AA150E70C/BKS 2016 Annual Report.PDF.}

18 David Streitfeld, Accusing Amazon of Antitrust Violations, Authors and Booksellers Demand Inquiry, N.Y. Times, July 13, 2015, https://www.nytimes. com/2015/07/14/technology/accusing-amazon-of-antitrust-violations-authors-and-booksellers-demand-us-inquiry.html? $\mathrm{r}=0$.

19 Olivia LaVecchia and Stacy Mitchell, How Amazon's Tightenng Grip on the Economy Is Stifling Competition, Eroding Jobs, and Threatening Communties (Institute for Local Self-Reliance Nov. 2016), https://ilsr.org/wp-content/uploads/2016/11/ILSR AmazonReport final.pdf.

20 European Commission - Press release, Antitrust: Commission seeks feedback on commitments offered by Amazon in e-book investigation, Brussels, Jan. 24, 2017, http://europa.eu/rapid/press-release IP-17-137 en.htm.

21 Statement of the Federal Trade Commission Regarding Google's Search Practices, In the Matter of Google Inc., FTC File Number 111-0163 (Jan. 3, 2013), https://www.ftc.gov/system/files/documents/public statements/295971/130103googlesearchstmtofcomm.pdf [hereinafter FTC Google Statement].

22 Federal Trade Commission Bureau of Competition, Report re Google Inc., Aug. 8, 2012, http://graphics.ws..com/google-ftc-report. A few caveats about this report, which the FTC released (mistakenly) under the Freedom of Information Act to the Wall Street Journal. First, only the Report's even pages were released, so the missing odd pages may have contained important qualifications. Second, other reports, including any prepared by Google, were not released. Third, although the Competition Staff recommended that the FTC sue Google, the Commissioners elected not to. Google responded to the Report's disclosure:

We understand that what was sent to the Wall Street Journal represents $50 \%$ of one document written by $50 \%$ of the FTC case teams. Ultimately both case teams (100\%) concluded that no action was needed on search display and ranking. Speculation about consumer or competitor harm turned out to be entirely wrong. On the other issues raised, we quickly made changes as agreed with the FTC.

The FTC Report on Google’s Business Practices, Wall Street Journal, March 24, 2015, http://graphics. wsj.com/google-ftc-report/.

$23 \mathrm{ld}$.

24 FTC Google Statement, supra note 21.

25 Samuel Gibbs, Getty Images Files Antitrust Complaint Against Google, The Guardian, April 27, 2016, https://www.theguardian.com/technology/2016/ apr/27/getty-images-files-antitrust-google.

26 European Commission - Press release, Antitrust: Commission sends Statement of Objections to Google on comparison shopping service; opens separate formal investigation on Android, Brussels, April 15, 2015, http://europa.eu/rapid/press-release IP-15-4780 en.htm. 
The e-monopsony and e-scraping concerns are not conjectural. MostAmericans, despite the gains in productivity, have experienced stagnant wages. The Council of Economic Advisers identifies monopsony power, rising concentration and monopoly pricing as hindering the U.S. economy. ${ }^{27}$

The concerns go beyond our wallet and can threaten our democratic ideals. The super-platforms are now an indispensable distribution channel for the news and books we read, the entertainment we watch and the music we listen. The super-platforms - in a directing our views of the world - can influence the marketplace of ideas and our elections. Jonathan Zittrain, for example, identified as a risk Facebook's ability to manipulate elections ${ }^{28}{ }^{2} \mathrm{He}$ warned of the super-platform's potential ability to predict political views, identify party affiliation and engage in targeted campaigning to mobilize distinct groups of voters to take action. Robert Epstein likewise argued how Google, in manipulating the rankings of its search results, "can easily shift the voting preferences of undecided voters by 20 percent or more - up to 80 percent in some demographic groups — with virtually no one knowing they are being manipulated." ${ }^{29}$ We have already seen instances in which super-platforms promoted certain corporate agendas. Google, for example, used its homepage to protest against the Stop Online Piracy Act (“SOPA"), asking users to petition Congress.

As worldwide web inventor Tim Berners-Lee noted:

Today, most people find news and information on the web through just a handful of social media sites and search engines. These sites make more money when we click on the links they show us. And, they choose what to show us based on algorithms which learn from our personal data that they are constantly harvesting. The net result is that these sites show us content they think we'll click on - meaning that misinformation, or 'fake news', which is surprising, shocking, or designed to appeal to our biases can spread like wildfire. And through the use of data science and armies of bots, those with bad intentions can game the system to spread misinformation for financial or political gain. ${ }^{30}$

One criticism is that the super-platforms shirk the legal and business responsibilities that the traditional media accept, such as responsibility for editorial opinion, paying the cost of investigative journalism and photojournalism, presenting both sides to a story, paying for content creation and liability for defamation. As a result, the tech companies operate in something of a "lawless zone" where they benefit from the ambiguity of their role. Thus, in dispensing with both journalists and editors, scraping others' content, not fairly compensating content providers and reinforcing the "filter bubble" effect, the super-platforms - rather than promoting the marketplace of ideas - can actually hinder it.

\section{CONCLUSION}

Ultimately, the super-platforms - in harming both the content providers upstream and consumers downstream - can undermine our economic well-being and democracy. Competition law has at its origins the protection of society from the misuse of economic and political power. Thus, our competition authorities must step up. Failing to challenge a super-platform's anticompetitive practices will only embolden it (and other aspiring gatekeepers). When the enforcer only looks down, upstream competition, innovation and the livelihood of many market participants, who deserve a competitive marketplace, will be hindered.

So if our politicians really care about our welfare, they should tell enforcers to start looking up. Doing so will help tackle America's concentration problem and help develop an inclusive data-driven economy that benefits more than one percent of the population. Looking up will also help promote a healthy democracy.

27 Council of Economic Advisers, Issue Brief: Labor Market Monopsony: Trends, Consequences, and Policy Responses (Oct. 2016).

28 Jonathan Zittrain, Facebook Could Decide an Election Without Anyone Ever Finding Out, The scary future of digital gerrymandering — and how to prevent it, New RepuBulc, June 1, 2014, https://newrepublic.com/article/117878/information-fiduciary-solution-facebook-digital-gerrymandering.

29 Robert Epstein, How Google Could Rig the 2016 Election: Google has the ability to drive millions of votes to a candidate with no one the wiser, Poutico, Aug. 19, 2015, http://www.politico.com/magazine/story/2015/08/how-google-could-rig-the-2016-election-121548.

30 Three Challenges for The Web, According to Its Inventor, Web Foundation, March 12, 2017, http://webfoundation.org/2017/03/web-turns-28letter/. 